Journal of Sustainable Development of Transport and Logistics

journal home page: http://jsdtl.sciview.net

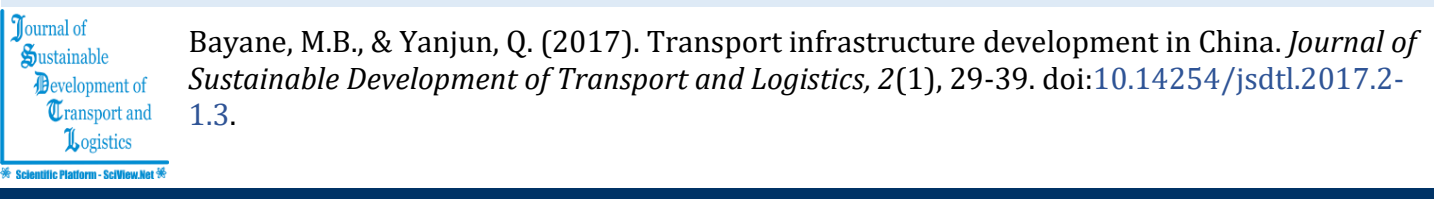

\title{
Transport infrastructure development in China
}

\section{Bouraima Mouhamed Bayane, Qiu Yanjun}

Southwest Jiaotong University,

Chengdu, Sichuan 610031, China

School of Civil Engineering, Key Laboratory of Highway Engineering

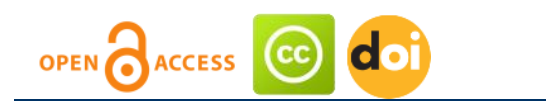

\section{Article history:}

Received: March, 2017

1st Revision: April, 2017

Accepted: May, 2017

\section{DOI:}

10.14254/jsdtl.2017.2-1.3

\begin{abstract}
This paper reviews the historical configuration process of transportation systems in China and examines the relationship between economic development and transport system at three different levels. The current status of transport infrastructure system development in China is summarized at national and regional level. The investment trends for transport infrastructure in China are also depicted. The keys issues relating to government initiatives are presented.
\end{abstract}

Keywords: transportation system, transportation history, investment, economic development

\section{Introduction}

Transport infrastructure contributes to the economic development of human society in industrial, agricultural or even knowledge-economy using post-industrial society. Since it is often mentioned as a key to promoting growth and development, it give a stimulus to the advancement of civilization and functions as an imperative for the world to avoid chaos and establish order. Historical construction of infrastructure such as railroads coincided with periods of rapid economic growth in Western Europe, Japan, and the United States. Thus, the significance of transportation development grows with social and economic development (Coyle et al., 2000).

Corresponding author: Bouraima Mouhamed Bayane

E-mail: soulsafmob@my.swjtu.edu.cn 
The history of the old civilization in China has witnessed an impressive in transportation development as well as social progress. The transportation development may find its historic achievements through a construction of road especially for the monarch riding of carriages in Chi Dao of Qin Dynasty, the Silk Road, a corridor to Western Regions in Han Dynasty, Zhaozhou Bridge built in Sui Dynasty, Lugou Bridge constructed in Jin Dynasty, and the posthouses of Tang and Song Dynasties. The construction of the Great Canal from Beijing to Hangzhou which was started in 5th century BC and completed in Sui Dynasty, for thousands of years, has made great contributions to the transportation of goods and the communication between the north and the south of China.

In 1405, a first fleet headed by Zheng He voyaged Southeast Asia and the Indian Ocean. It was made up of 317 ships with 2800 people on board. This trip was beyond the imagination of the Europeans in the Middle Ages. Up to the year 1431, 7 important voyages have been at least made by Chinese to prove its capability to the outside world. These voyages have significant benefits to Chinese since they have returned with rare animals and certain precious and medicable vegetables and minerals (Landers, 2001). Although great efforts have been made by the people of ancient China in transportation culture, the country has been lagging far behind the industrialized western countries in transportation since Industrial Revolution in the West ushered in mineral and mechanical- powered modern transportation.

The productivity of the transportation industry has redoubled with the innovations of new technology and new energy, together with the institutional innovation of "market revolution" (Zhang, 1991). People who were separated from one another have been sent onto the path of economic globalization due to the constant progress of modern transportation and communications technologies. With the industrial revolution, transportation, as an indication of technological advancement and civilization succession, has been accelerating its growth for the past 200 years in the history of transportation development of developed countries. From 1950, the development undergoes several phases, from water and railway transportation, to the corresponding development of five means of transportation: railway transportation, road transportation, water transportation, air transportation, and pipeline transportation as a result of technological progress in high-speed railway, superhighway, super ships, large jet planes, and container transportation technology. Transportation is recently more than just a tool of shortening distance and saving time. It has become an indispensable part of modern society from the function as a traveling vehicle in daily life to production and circulation in economic society, from regional economic exploitation to national defense construction. It has been served as a bridge to enhance communication, open to the outside world, promote space integration, link economy and trade, and push on social progress. It has also become the foundation of order stabilization in the civilized society.

Since the founding of the People's Republic of China in 1949, especially since the economic reforms began in 1978 and the fiscal decentralization in the 1990s, there has been a rapid development in China's transportation. Powerful transportation infrastructures have replaced the poor ones, the port infrastructures became the most powerful in the world, the mileage of highway used by traffic has moved forward to the second position in the world and of railway business to the third (Wang, 2004), the world Passenger and freight volumes the largest, and airports and civil aviation among the top in the world. The industry of China's transport has entered a period of sound progress with the transport technologies which keep increasing. With the improvement of the State Council, the transport planning has been set up, and transport installations network is under all-round construction.

\section{Relationship between economic development and transport system}

Transportation infrastructures are among the foremost issues in the development of China; and include roads, railways, ports, airports, and waterways. They have been one of the major engines of China's economic growth (Fan, Bai, \&Pan, 2004; Lou, 2003; Zhang, 2009). There is actually internal links between economic development and transport, which is important to thoroughly understand for China's macro-management of transport development. The analysis of the internal links is at three levels: macroeconomic level, microeconomic level, and general equilibrium. The relationship between economic development and transport system based on the three levels are summarized in Table 1. 


\begin{tabular}{|c|c|}
\hline Levels & \\
\hline Macroeconomic & $\begin{array}{l}\text { - Appropriate transport planning induced economic development (World } \\
\text { Bank, 1995) } \\
\text { - Inadequate transport infrastructure creates economic development } \\
\text { bottlenecks (Wang, 2006). } \\
\text { - Transports services as the largest infrastructure absorb 5\%-8\% of working } \\
\text { population in infrastructure related services }\end{array}$ \\
\hline Microeconomic & $\begin{array}{l}\text { - Improvement of transport infrastructure reduced spatial economic } \\
\text { development } \\
-\quad \text { Access of transports users to cheaper and reliable services } \\
-\quad \text { Improvement of logistics services } \\
-\quad \text { Reduction of redundant production facilities } \\
-\quad \text { Convergence and proliferation of regional economic activities } \\
-\quad \text { Increase of goods and/or services added value } \\
-\quad \text { Promotion of economic development and social progress } \\
-\quad \text { Free flow of people and commodities between the production and } \\
\text { consumption } \\
-\quad \text { Reduction of element costs } \\
-\quad \text { Improvement of the mobility and transfer of production elements } \\
-\quad \text { Exposure of people to a wider range of community facilities } \\
-\quad \text { Provide better publics goods (Button, 1998) }\end{array}$ \\
\hline $\begin{array}{l}\text { General } \\
\text { equilibrium }\end{array}$ & $\begin{array}{ll}- & \text { Reduction of transport cost } \\
- & \text { Improvement of allocation of resources } \\
- & \text { Improvement of service quality } \\
- & \text { Providence of more opportunities for the development of low-income areas } \\
- & \text { by linking both developed and under-developed regions } \\
- & \text { Narrow of gap between regions } \\
- & \text { Promotion of land development and social equity } \\
& \text { preparedness system }\end{array}$ \\
\hline
\end{tabular}

\section{Current status of transport infrastructure development in China}

\subsection{National level}

\subsubsection{Highways}

China's highway carried a total of 16,190,970,000 passengers in 2015 against 16,973,810,000 passengers in 2005, a decrease of 782840 passengers. The total highway passenger-km increased by 1,074,270 million passenger-km in 2015 against 929210 million passenger-km in 2005. The volume of freight dispatched by the highway in China amounted to 31,500,190,000 tons in 2015 against $13,417,780,000$ tons in 2005. The total highway freight-ton-km reached 5,795,570 million ton-km in 2015 against 869,320 million ton-km in 2005 . Highways length has increased from 3,345,200 km in China from 1978 to 2015, reaching 4,577,300 km in 2015. The layout of the road network has further improved. The technical grades and road surface grades have been both upgraded. Highway construction has broken through the historical records. Road length in the counties and towns has continuously and rapidly increased. The road density has also increased, and the accessibility by roads has been improved. All the data explained above are summarized in Figure 1. 


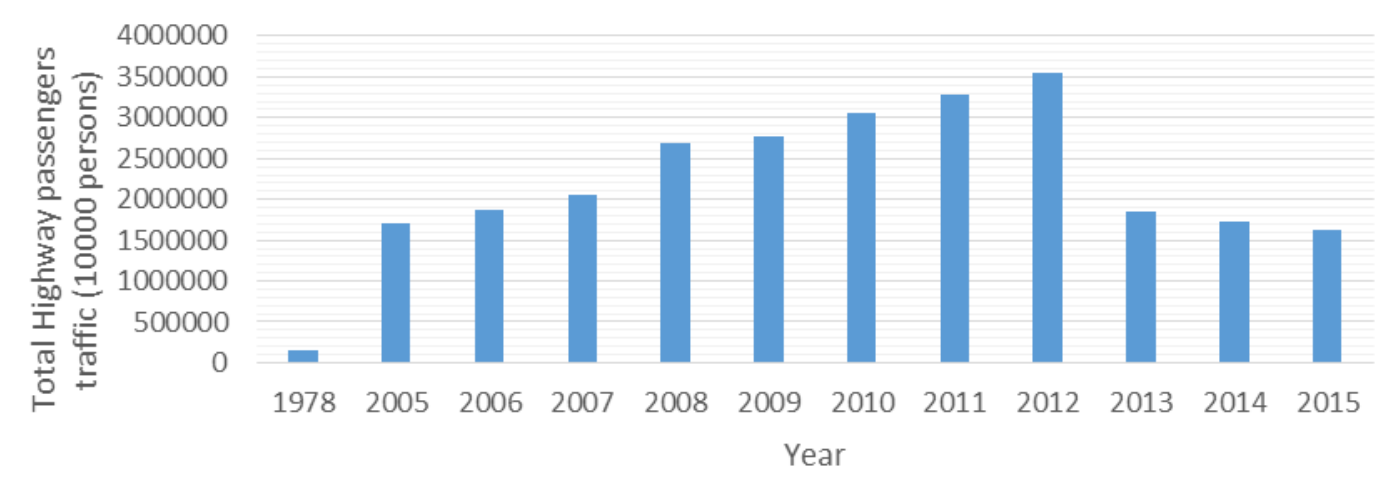

a) Total highway passenger traffic in China, 1978-2015

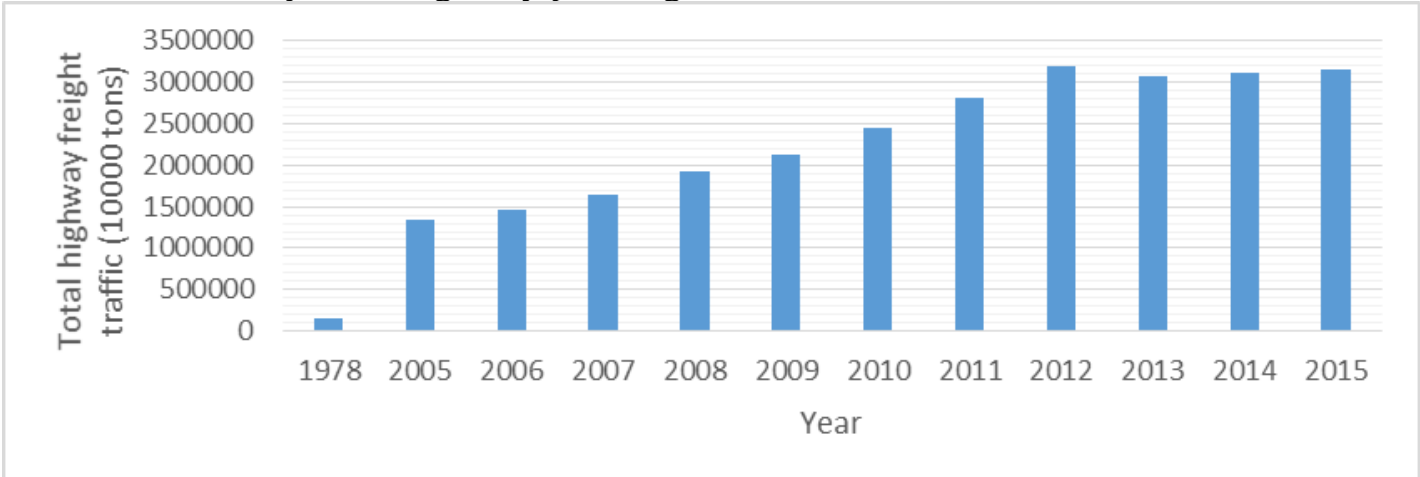

b) Total highway freight traffic in China, 1978-2015

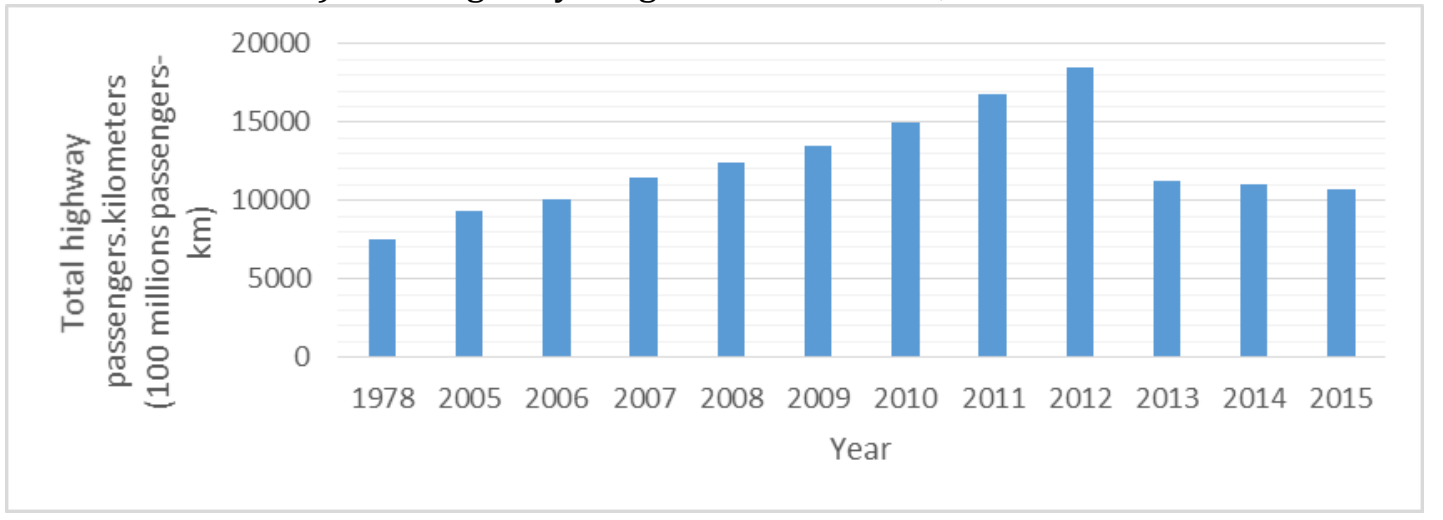

c) Total highway passenger kilometers in China, 1978-2015

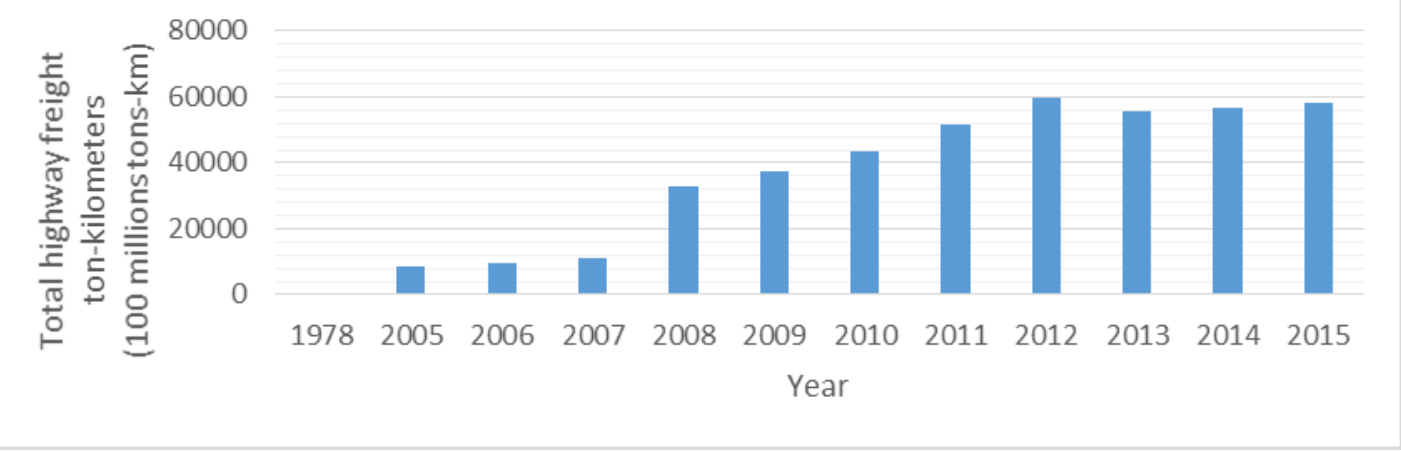

d) Total highway freight-ton-kilometers in China, 1978-2015

Fig. 1. Highway passenger and freight traffic in China. Data were collected by the authors based on the China Statistical Yearbook in various years (1978-2015)

\subsubsection{Railways}

By the end of 2015, the length of running railways was $121,000 \mathrm{~km}, 37.6$ percent up from 2005. Passengers by Rail in 2015 reached 2,534,840,000 against $1,155,830,000$ passengers from 2005 year. The total railway passenger-km was 1,196,060 million passenger-km in 2015 against 606200 million passenger-km in 
2005. The total freight capacity was about 3,358,010,000 tons in 2015 against $2,692,960,000$ tons in 2005 . The total railway freight-ton-km increased to $2,375,430$ million ton-km in 2015 while it was 2,072,600 million ton-km in 2005. Figure 2 shows the railway transportation development within the period, 1978-2015.

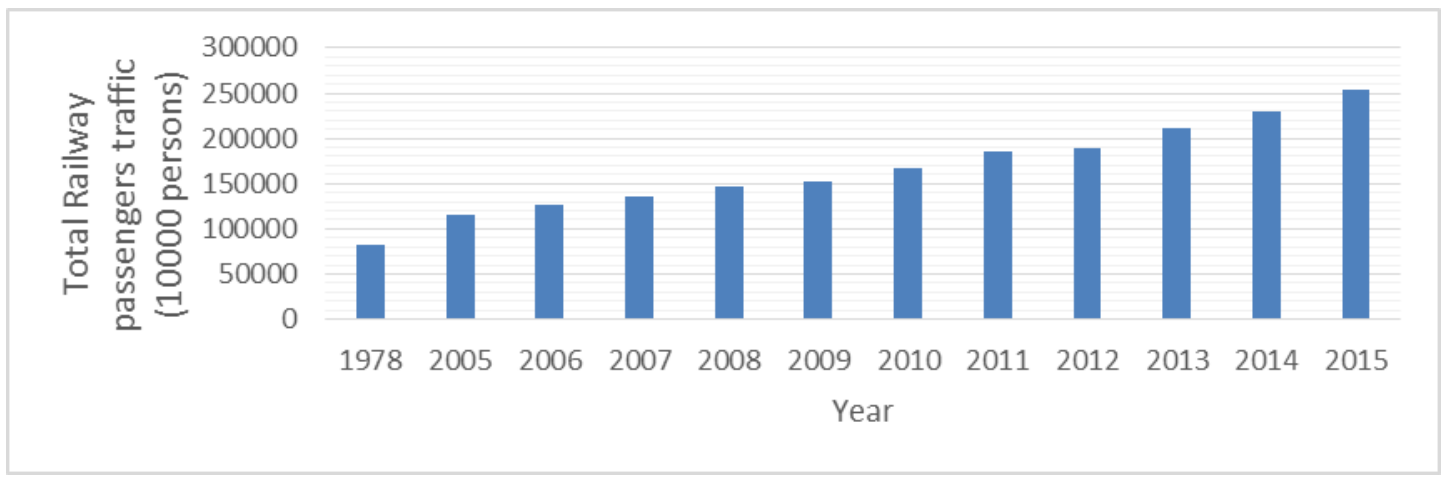

a) Total railway passenger traffic in China, 1978-2015

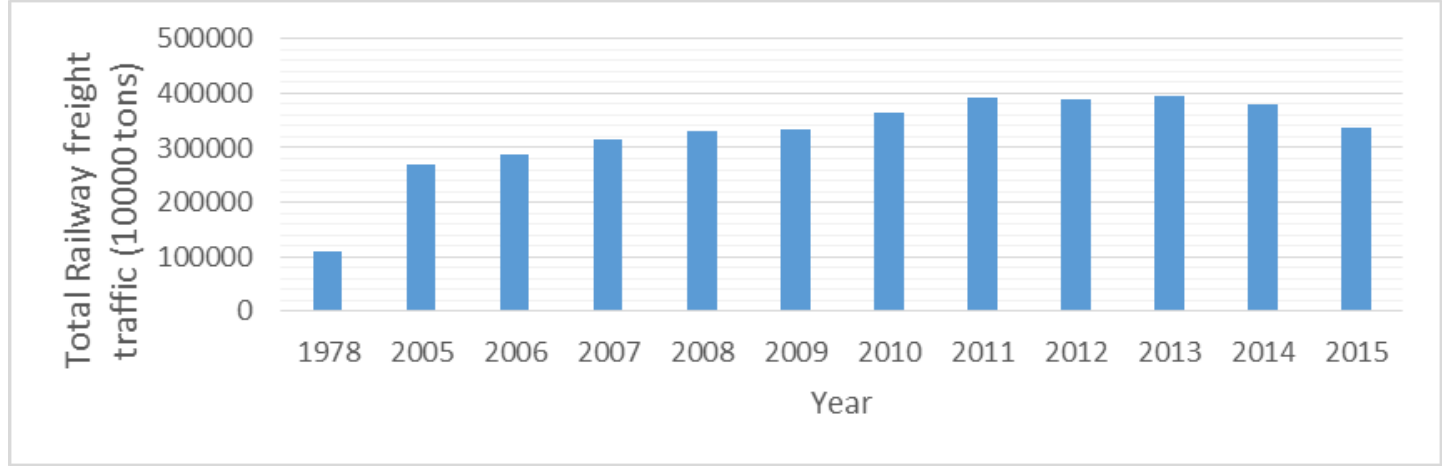

b) Total railway freight traffic in China, 1978-2015

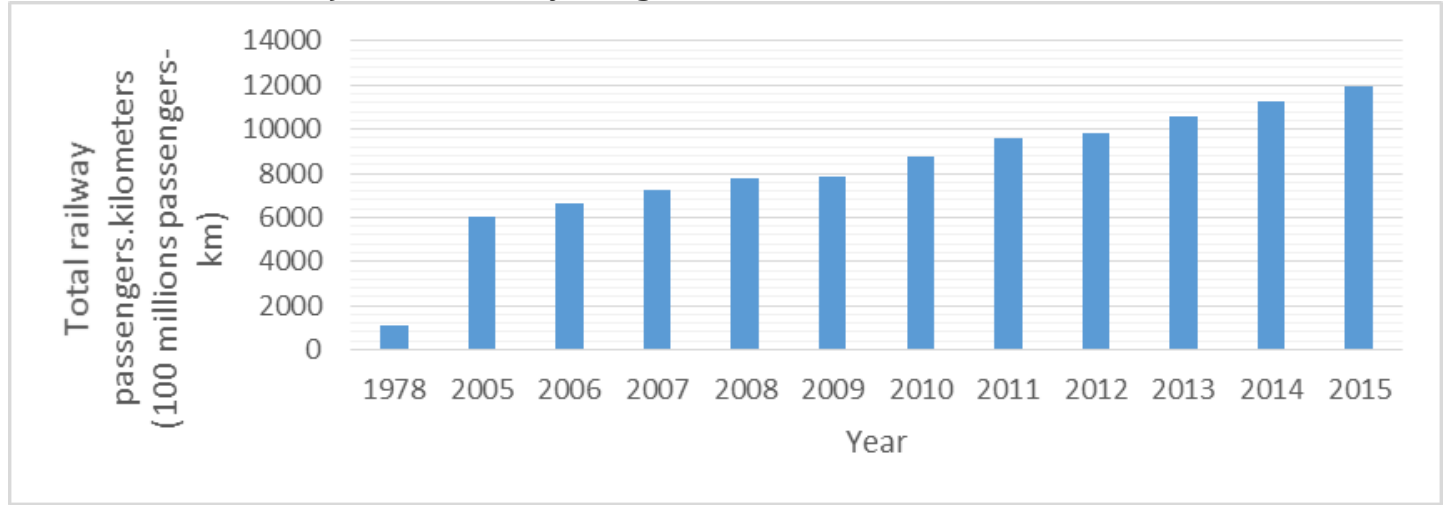

c) Total railway passenger kilometers in China, 1978-2015

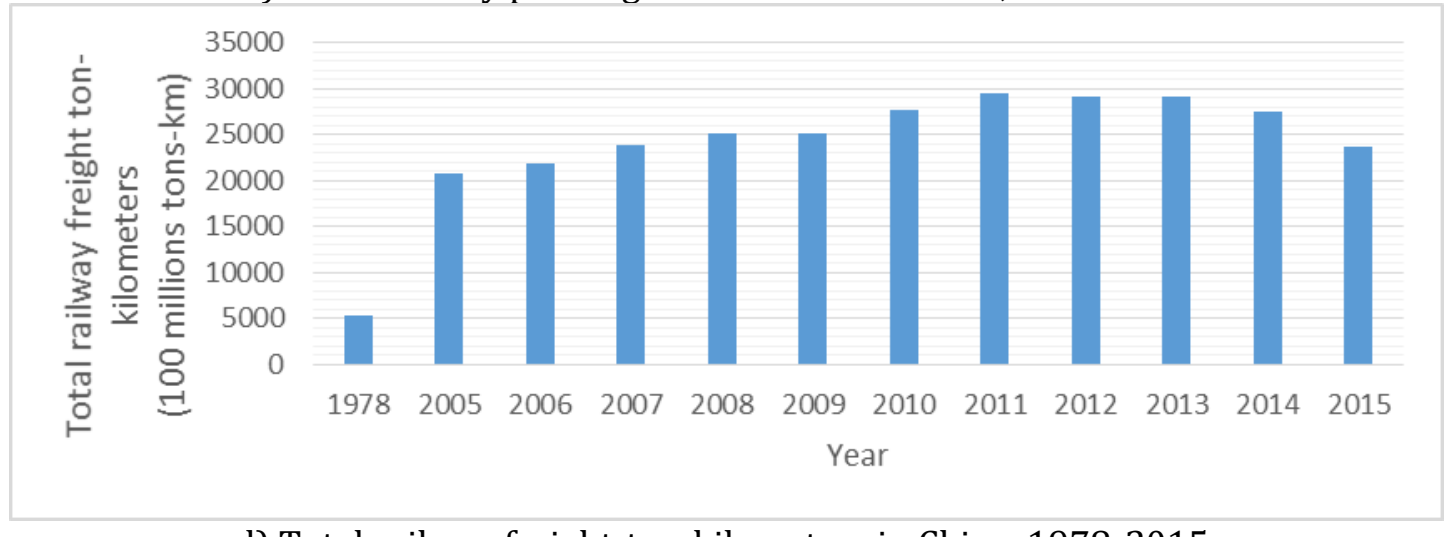

d) Total railway freight-ton-kilometers in China, 1978-2015

Fig. 2. Railway passenger and freight traffic in China. Data were collected by the authors based on the China Statistical Yearbook in various years (1978-2015) 


\subsubsection{Waterway}

The total transportation capacity of the freight increased $2,196,480,000$ tons in the 2005 year from to $6,135,670,000$ tons in the 2004 year. The total waterway passenger traffic reached $270,720,000$ passengers in the 2015 year against 202,270,000 in the 2005. The total waterway passenger-km and freight-ton-kilometer were 7,130 million and 9,177,250 million respectively against 6,780 million and 4,967,230 million in the 2005 year. The development of waterway transportation is shown through Figure 3.

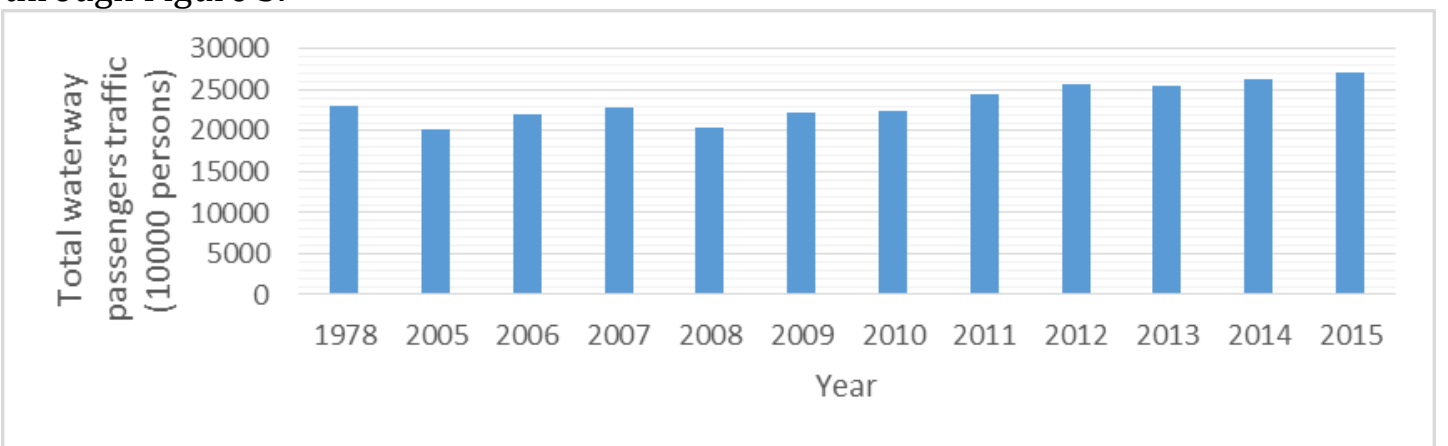

a) Total waterway passenger traffic in China, 1978-2015

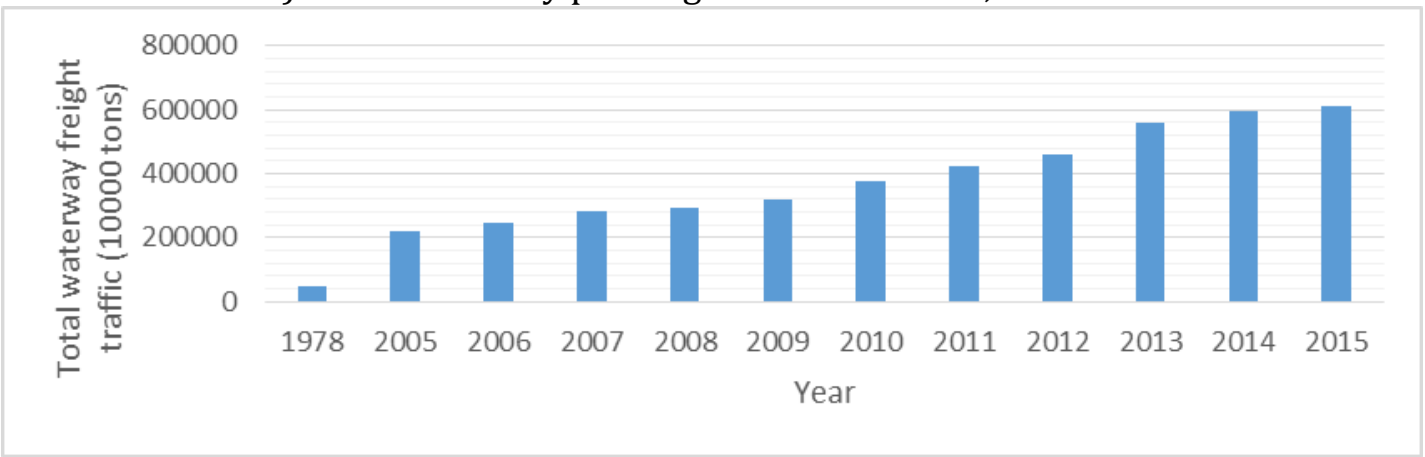

b) Total waterway freight traffic in China, $1978-2015$

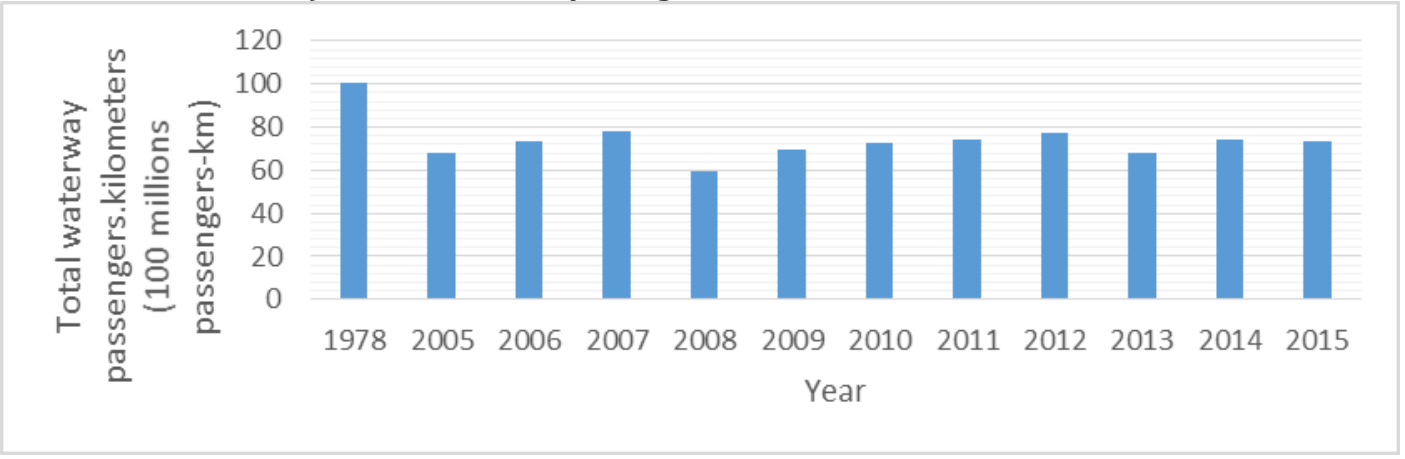

c) Total waterway passenger kilometers in China, 1978-2015

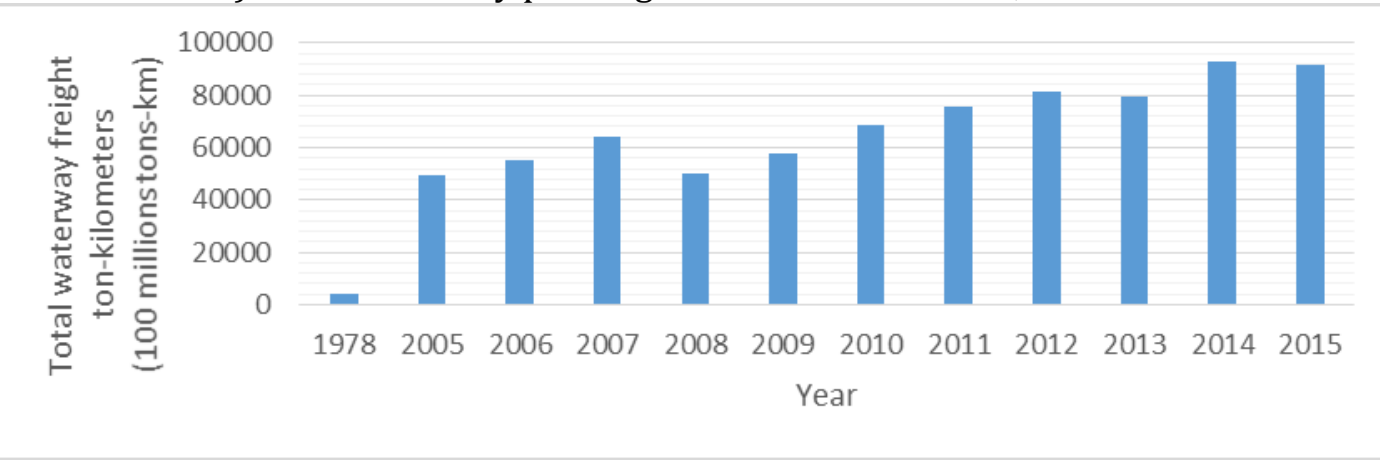

d) Total waterway freight-ton-kilometers in China, 1978-2015

Fig. 3. Waterway passenger and freight traffic in China. Data were collected by the authors based on the China Statistical Yearbook in various years (1978-2015) 


\subsubsection{Airline}

The civil airline of China became the second large air transportation system in the world, next to the United States, in 2005, based on data on the total turnover of regular airlines by the International Civil Airline Organization of the Member States. China has the fastest growing passenger air market of any country in the world (by total passenger numbers) and between 2005 and 2015 the number of passengers increased 3 times from 138,270,000 to 436,180,000. The total railway passenger-km was 728,260 million passenger-km in 2015 against 204,490 million passenger-km in 2005. The total freight capacity was about 6,293,000 tons in 2015 while 3,067,000 tons is registered in 2005. The total airline freight-ton-km increased to 20,807 million ton-km in 2015 while it was 7,890 million ton-km in 2005. Figure 4 presents the airline passenger and freight traffic along with passenger-kilometer and freight-ton-kilometer.

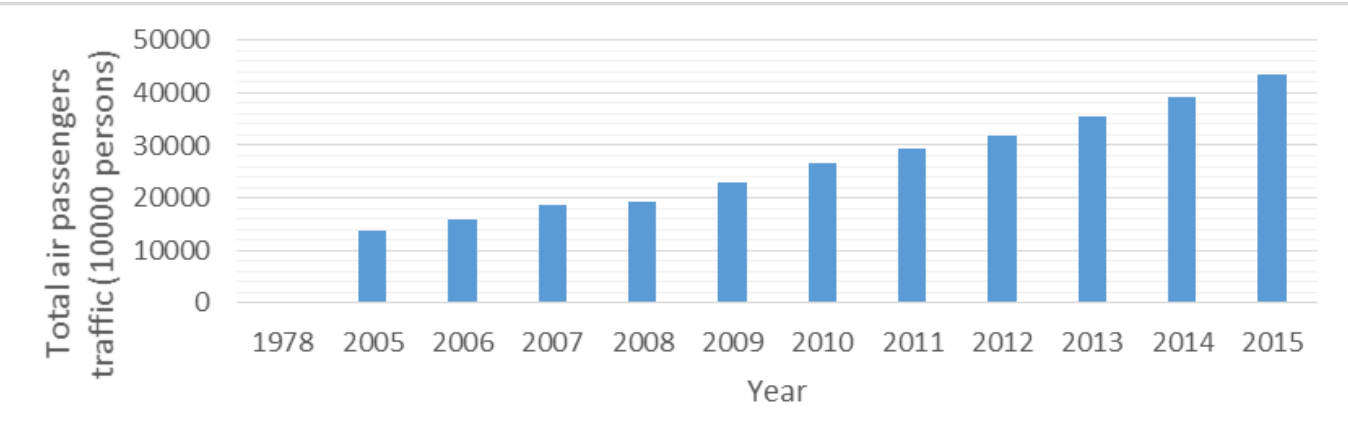

a) Total air passenger traffic in China, 1978-2015

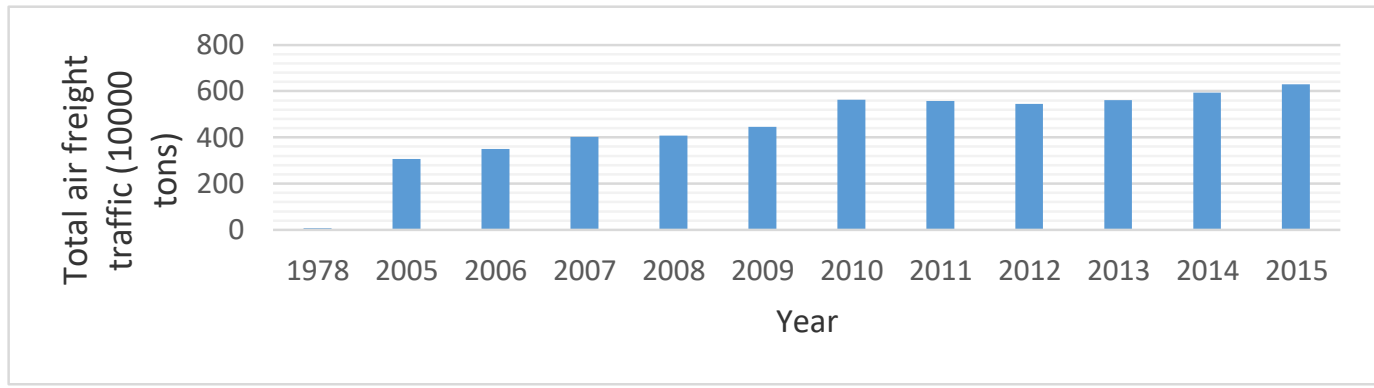

b) Total air freight traffic in China, 1978-2015

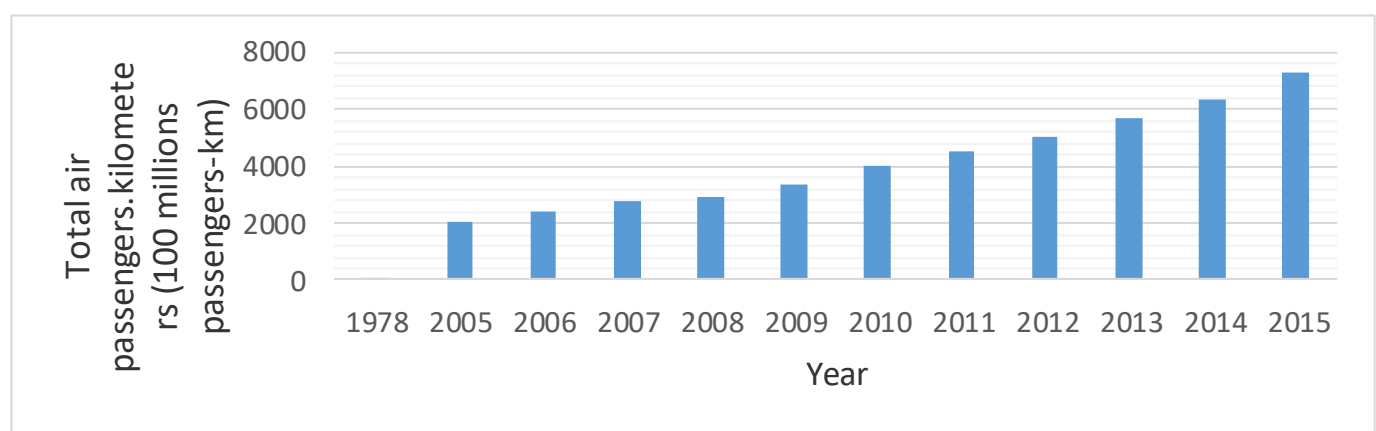

c) Total air passenger kilometers in China, 1978-2015

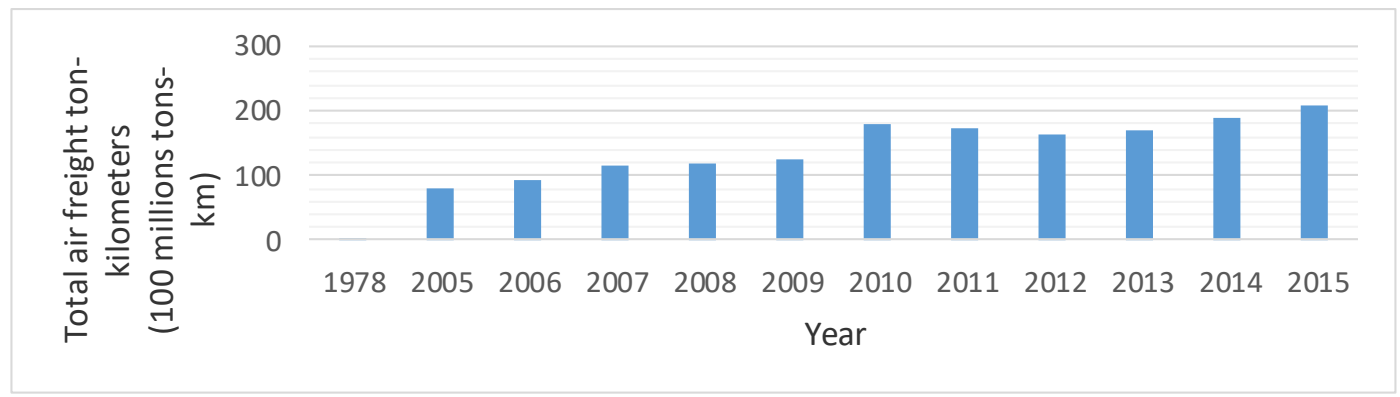

d) Total air freight-ton-kilometers in China, 1978-2015

Fig. 4. Air passenger and freight traffic in China. Data were collected by the authors based on the China Statistical Yearbook in various years $(1978-2015)$ 


\subsection{Regional level}

As the world's largest developing country, China's has various geographic conditions in different parts for building transport infrastructures. It also has experienced interprovincial inequality growth during its transition process to a market-based economy. Studies by Fan and Sun (2008) show that there was declining inequality since 2004 . These studies have also pointed out various factors that drive regional inequality such as human capital endowment, infrastructure, coastal location, fiscal transfer, deregulation of private enterprises, and Open-Door Policy that attract FDIs. Studies by Kanbur and Zhang (2005) attributed regional inequality to three key policy variables: the ratio of heavy industry, the degree of decentralization and the degree of openness. The ladder-step development strategy has been carried out by China in the early stages of economic reform. The government has encouraged certain regions to get rich quickly (Wei, 1999), that what explains the higher economic growth and a more advanced infrastructure in the eastern region since 1978. China's transport infrastructure has been shaped by diverse institutional reforms and policy over 60 years (Fan \& Chan-Kang, 2008).

In the 1960s, heavy industry was favored due to infrastructure investments by centralized decision-making structure. Areas such North-Eastern China, where most of the heavy industry were based, have noticed the rapid development of transport network. More specially, railway development was a priority over other types of transport, to carry huge quantity of resources and raw materials. As result of heavy industry in the North-Eastern China, it can be seen from Table 2, that among all the regions in China, eastern China registered the highest railway passenger traffic, with 786,960,000 persons in 2015 while Northern China ranked first in terms of volume of freight dispatched by railway in the same year. Central \& Southern registered the highest highway passenger traffic, with nearly $4,696,890,000$ passengers in 2015. Eastern ranked second in terms of highway passenger traffic and amounted to 4,349,830,000 passengers. Water transportation in China could be generally categorized under "ports" and "inland waterways". According to the National Bureau of Statistics (NBS), China's waterway carried a total $270,720,000$ passengers in 2015. Eastern's waterway carried a total of $110,720,000$ passengers in 2015. The waterway passenger traffic of Eastern ranked first among all the regions in China. It also ranked first in terms of the waterway freight traffic in China (Table 2). Based on China Airport production statistics bulletin in 2015, the eastern region has registered the highest air passenger and freight traffics with 265,945,725 passengers and 5,731,599. 56 tons respectively.

Table 2. Passenger and freight traffic by regions in China
\begin{tabular}{|c|c|c|c|c|c|c|c|c|}
\hline & \multicolumn{2}{|c}{ Railways } & \multicolumn{2}{c|}{ Highways } & \multicolumn{2}{c|}{ Waterways } & \multicolumn{2}{c|}{ Civil air } \\
\hline $\begin{array}{c}\text { Region } \\
\text { in } \\
\text { China }\end{array}$ & $\begin{array}{c}\text { Passenger } \\
\text { traffic }\end{array}$ & $\begin{array}{c}\text { Freight } \\
\text { traffic }\end{array}$ & $\begin{array}{c}\text { Passenger } \\
\text { traffic }\end{array}$ & $\begin{array}{c}\text { Freight } \\
\text { traffic }\end{array}$ & $\begin{array}{c}\text { Passenger } \\
\text { traffic }\end{array}$ & $\begin{array}{c}\text { Freight } \\
\text { traffic }\end{array}$ & $\begin{array}{c}\text { Passenger } \\
\text { traffic }\end{array}$ & $\begin{array}{c}\text { Freight } \\
\text { traffic }\end{array}$ \\
\hline 1 & 39,204 & 153,376 & 140,815 & 435,972 & 186 & 14,410 & $14,552.01$ & 140.01 \\
\hline 2 & 29,942 & 29,907 & 121,914 & 255,048 & 1,064 & 14,877 & $5,488.49$ & 48.87 \\
\hline 3 & 78,696 & 45,883 & 434,983 & 930,346 & 11,072 & 363,896 & $26,594.57$ & 573.15 \\
\hline 4 & 68,062 & 33,186 & 469,689 & 846,948 & 7,362 & 177,568 & $21,552.07$ & 364.86 \\
\hline 5 & 22,272 & 20,041 & 306,750 & 406,964 & 6,652 & 25,698 & $15,630.06$ & 232.246 \\
\hline 6 & 15,305 & 53,415 & 14,945 & 274,745 & 733 & 252 & $7,927.1$ & 50.249 \\
\hline
\end{tabular}

Note: Data were collected from China Statistical Yearbook (published by State Statistical Bureau) in 2015.

(1: Northern): Beijing, Hebei, Inner Mongolia, Shanxi, and Tianjin.

(2: Northeastern): Jilin, Liaoning, Heilongjiang.

(3: Eastern): Anhui, Jiangsu, Shanghai, Zhejiang, Fujian, Shangdong, and Jiangxi.

(4: Central \& Southern): Henan, Hubei, Hunan, Guangdong, Guangxi, and Hainan.

(5: Southwestern): Chongqing, Guizhou, Sichuan, Tibet, and Yunnan.

(6: Northwestern): Gansu, Ningxia, Shaanxi, Xinjiang, and Qinghai

Passenger traffic in (10000 persons) unit

Freight traffic in (10000 tons) unit 


\section{The expansion of transport infrastructure along with investment}

With economic reforms in 1978 and fiscal decentralization in the 1990s, both central and local governments have increased the investment in various types of "transport facilities". As Table 3 shows, the total investment in fixed transport infrastructure was 2777.457 billion in 2015, almost 4 times the size of the year 2005 .

As the result of these investment levels, the performance of China's transport has improved in the last decades. All types of transport infrastructure have seen a significant increase in these years, as can be also seen in Table 4.

Despite great efforts by the central and local governments to improve transport infrastructure, China's service is still insufficient to satisfy the huge demand induced by its booming economy especially during the "Spring Festival" and the "Golden Weeks". The traffic jams and pollution in big cities, the inadequate basic transportation services in rural and remote areas and the problems in the transportation of coal are among the transport problems, which have a great negative impact on the economic development. Therefore, China's transport system is still incapable to completely satisfy the demand of passengers and enterprises although; it has witnessed a great improvement of its transport facilities. Due to rapid economic growth and rapid increase demand for mobility, a new round of transport bottlenecks is emerging. The government has then taken some initiatives to solve these problems mentioned above.

The outline of the Thirteen Five-Year Plan for National Economic and Social Development approved by the Fourth Session of 12th National People's Congress makes a blueprint for the national economic and social development in the next five years. It is pointed that the Thirteen Five-Year Plan period China's transport development should "build a comprehensive transportation system that connects domestic and international transportation routes, develop modern and efficient urban intercity transportation, develop comprehensive international hubs, make a headway in the low carbon, smart and safe transportation. The Key development goals for transport infrastructure by

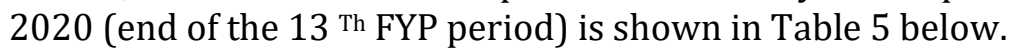

\begin{tabular}{|l|c|}
\hline \begin{tabular}{|} 
Table 3. Investment in fixed asset in transport infrastructure \\
\hline $\begin{array}{c}\text { Transport infrastructure } \\
\text { mode }\end{array}$ & $\mathbf{2 0 0 5}$ & $\mathbf{2 0 1 5}$ \\
\hline Highways & 548,49 billion yuan & $1,651.33$ billion yuan \\
\hline Railways & 88 billion yuan & 823.8 billion yuan \\
\hline Waterways & 68.877 billion yuan & 145.717 billion yuan \\
\hline Civil aviation & 21.12 billion yuan & 156.61 billion yuan \\
\hline Total & 726.587 & 2777.457 \\
\hline
\end{tabular}
\end{tabular}

Note: Data for civil aviation were obtained from Civil Aviation Administration of China, $\ll$ The civil aviation industry development statistical bulletin in 2015》 and data for (highways, railways, and waterways) were obtained from Ministry of Transport of the People's Republic of China, «The transportation industry development statistical bulletin in 2015》.

\begin{tabular}{|c|c|c|c|c|}
\hline Year & $\begin{array}{l}\text { Length of railways } \\
\text { in operation } \\
(x 10000 \mathrm{~km})\end{array}$ & $\begin{array}{l}\text { Length of highways } \\
(\times 10000 \mathrm{~km})\end{array}$ & $\begin{array}{c}\text { Length of } \\
\text { navigable inland } \\
\text { waterways } \\
(x 10000 \mathrm{~km})\end{array}$ & $\begin{array}{c}\text { Length of regular } \\
\text { civil aviation } \\
\text { routes }(x 10000 \\
\text { km) }\end{array}$ \\
\hline 2005 & 7.54 & 334.52 & 12.33 & 199.85 \\
\hline 2010 & 9.12 & 400.82 & 12.42 & 276.51 \\
\hline 2015 & 12.10 & 452.73 & 12.70 & 531.72 \\
\hline
\end{tabular}

Note: Data for civil aviation were obtained from China Statistical Yearbook, 2016. 


Table 5. Key development goals for transport infrastructure by 2020 (end of the 13 Th FYP
periods)
\begin{tabular}{|l|c|c|c|}
\multicolumn{1}{|c|}{ Indicators } & Unit & $\mathbf{2 0 1 5}$ & By 2020 \\
\hline $\begin{array}{l}\text { Length of railways in } \\
\text { operation }\end{array}$ & $` 000 \mathrm{~km}$ & 121 & 150 \\
\hline Electrified & $\%$ & 61 & 70 \\
\hline $\begin{array}{l}\text { Length of highways in } \\
\text { operation }\end{array}$ & $` 000 \mathrm{~km}$ & 4,580 & 5,000 \\
\hline Coastal deep water & Unit & 2,207 & 2,527 \\
\hline Number of civil airports & Unit & 207 & 260 \\
\hline
\end{tabular}

\section{Conclusion}

Transportation is a leading quantity to make the development of social productivity and the improvement of science and technology. In the master plan and long run plan of national economic and social development, transportation plan should be considered not only in the transportation mode itself but also in the context of transportation orientation development.

Transportations of China once had a prosperous time, but it still has season, time-limiting, and regional imbalance as major characteristics. Golden weeks transport, spring festival and transport of migrant's labors are the tough nuts to crack. Coal transportation from West-to-east and North-toSouth being the foremost transport of freight traffic; solutions towards the problems of transport development aggregate, structure, quality, and efficiency must be found.

The current status of China's transportation shows that it necessary to implement the outline of the Thirteen Five-Year Plan which adhere to a comprehensive transportation system that connects domestic and international transportation routes, develop modern and efficient urban intercity transportation, develop comprehensive international hubs, make a headway in the low carbon, smart and safe transportation.

\section{Appendix A. Supplementary material}

Supplementary data associated with this article can be found, in the online version, at http://jsdtl.sciview.net

\section{Funding}

The authors received no direct funding for this research.

\section{Citation information}

Bayane, M.B., \& Yanjun, Q. (2017). Transport infrastructure development in China. Journal of Sustainable Development of Transport and Logistics, 2(1), 29-39. doi:10.14254/jsdtl.2017.2-1.3.

\section{References}

Button, K. (1998). The good, the bad and the forgettable - or lessons the US can learn from European transport policy. Journal of Transport Geography, 6(4), 285-294.

Civil aviation industry development statistical bulletin. (2005-2015). Civil Aviation Administration of China.

Coyle, J.J., Bardi, E.J., \& Novack, R.A. (2000). Transportation, 5th Edition. Cincinnati: South-western College publishing.

Fan, C.C., \& Sun, M. (2008). Regional inequality in China, 1978-2006. Eurasian Geography and Economics, 49(1), 1-18.

Fan, J., Bai, B., \& Pan, Q. (2004). Progress made by the study on the contribution of infrastructure capital to economic growth - A summary of the method of production function. Modern Economic Science, 26(2), 87-96. 
Fan, S., \& Chan-Kang, C. (2008). Regional road development, rural and urban poverty: Evidence from China. Transport Policy, 15(5), 301-314.

Kanbur, R., \& Zhang, X. (2005). Fifty years of regional inequality in China: a journey through central planning, reform, and openness. Review of Development Economics, 9(1), 87-106.

Landers, D.S. (2001). Rich Country, Poor Country. Beijing, China: Xinhua Publishing House.

Lou, H. (2003). Study on infrastructure investment and economic growth. PhD Dissertation, Tsinghua University.

Ministry of Transport of the People's Republic of China. (2005-2015). Transportation industry development statistical bulletin 2015.

Report on World Development. (1995). World Bank.

State Statistical Bureau (SSB). (1978-2015). China statistical yearbook. Beijing: China Statistical Publishing House.

Wang, Q.Y. (2005). On approaches and practice of comprehensive transport network planning. Journal of Transportation Systems Engineering and Information Technology, 5(1), 11-15.

Wang, R.F., \& Wang, J.J. (2006). The output elasticity and optimal scale - study based on gross production function. Economic Science, 2.

Wei, Y.D. (1999). Regional inequality in China. Human Geography, 23(1), 49-59.

Zhang, G.W. (1991). Transportation System Analysis. Chengdu, China: Southwest Jiaotong University Publishing House.

Zhang, X. (2009). Transport infrastructure, spillover and regional economic growth. Nanjing: Nanjing University Press.

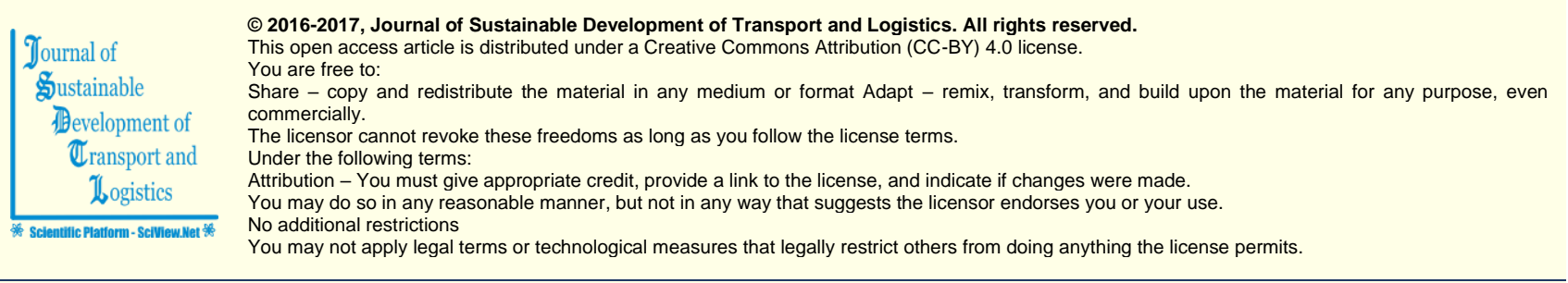

Journal of Sustainable Development of Transport and Logistics (ISSN: 2520-2979) is published by Scientific Publishing House "CSR",

Poland, EU and Scientific Publishing House "SciView", Poland, EU

Publishing with JSDTL ensures:

- Immediate, universal access to your article on publication

- High visibility and discoverability via the JSDTL website

- Rapid publication

- Guaranteed legacy preservation of your article

- Discounts and waivers for authors in developing regions

Submit your manuscript to a JSDTL at http://jsdtl.sciview.net/ or submit.jsdt!@sciview.net 